Bull. Chem. Soc. Ethiop. 2020, 34(3), 449-462.

ISSN 1011-3924

(c) 2020 Chemical Society of Ethiopia and The Authors

Printed in Ethiopia

DOI: https://dx.doi.org/10.4314/bcse.v34i3.2

\title{
LEVELS OF SELECTED METALS IN TEFF GRAIN SAMPLES COLLECTED FROM THREE DIFFERENT AREAS OF ETHIOPIA BY MICROWAVE PLASMA-ATOMIC EMISSION SPECTROSCOPY
}

\author{
Abraha Gebregewergis ${ }^{1,2}$, Bhagwan Singh Chandravanshi ${ }^{1 *}$ and Mesfin Redi-Abshiro ${ }^{1}$ \\ ${ }^{1}$ Department of Chemistry, College of Natural and Computational Sciences, Addis Ababa \\ University, P.O. Box 1176, Addis Ababa, Ethiopia \\ ${ }^{2}$ Kulumsa Agricultural Research Center, P.O. Box 489, Asella, Ethiopia, Ethiopian Institute of \\ Agricultural Research, P.O Box 2003, Addis Ababa, Ethiopia
}

(Received March 14, 2020; Revised November 2, 2020; Accepted November 11, 2020)

\begin{abstract}
The levels of selected essential and non-essential metals in the white, red, and mixed teff grains collected from Bure, Debre Markos and Bahir Dar (Ethiopia) were determined by microwave plasma-atomic emission spectroscopy (MP-AES). After proper sample pretreatment, the powdered teff was wet digested with the acid mixture $\left(5 \mathrm{~mL} \mathrm{HNO}_{3}: 1 \mathrm{~mL} \mathrm{HClO}_{4}\right)$ at $240{ }^{\circ} \mathrm{C}$ for $2: 30 \mathrm{~h}$ over Kjeldhal digestion block. The accuracy of the optimized procedure was evaluated by analyzing the digest of the spiked samples with a standard solution of metals, and the percentage recoveries varied from $92 \%$ to $104 \%$. The mean concentrations of metals determined $(\mathrm{mg} / \mathrm{kg}$, dry weight) were in the ranges of $\mathrm{Al}(713-1513)>\mathrm{Fe}(252-1195)>\mathrm{Ca}(233-348)>\mathrm{Zn}(69-102)>\mathrm{Mn}$ $(20-45)>\mathrm{Cu}(13-15)>\mathrm{Pb}(1.8-2.8)>\mathrm{Cd}(0.8-1.8)$. In this study, $\mathrm{Al}$ and $\mathrm{Cd}$ were determined in the teff for the first time. Analysis of variance indicated no significant difference between the mean concentrations of $\mathrm{Cu}$ and $\mathrm{Mn}$ among the white teff samples, Mn among the red teff samples and $\mathrm{Cd}$ and $\mathrm{Pb}$ among the mixed teff samples, but there was a significant difference for the other studied metals among the corresponding teff samples at $95 \%$ confidence level.
\end{abstract}

KEY WORDS: Teff grain, Eragrostistef(Zucc.) Trotter, Essential metals, Non-essential metals, Ethiopia

\section{INTRODUCTION}

Teff [Eragrostistef (Zucc.) Trotter] is one of the major and indigenous cereal crops in Ethiopia, where it was originated [1]. It is considered a low-risk crop from the perspectives that it can be cultivated in a broad range of ecological surroundings and under tough environmental conditions. Teff can grow in altitudes ranging from sea level to 2800 meters above sea level under different moisture, soil, temperature, and rainfall regimes. It grows in dry as well as water-logged soils, can tolerate anoxic situations better than maize, wheat, and sorghum and is resistant to many pests and diseases [2]. Teff is best suited for cultivation in a warm climate with temperatures ranging from 10 to $27{ }^{\circ} \mathrm{C}$ and altitudes of $(1,000-2,100 \mathrm{~m})$. In Ethiopia, the crop occupies over 2.8 million hectares, equivalent to $25-30 \%$ of the total area covered by cereals. In terms of production, teff is the dominant cereal by area coverage and second only to maize in production and consumption [3].

With a population exceeding 112 million people, Ethiopia is the only country in the world where teff is intensely grown and produced for human consumption. Teff is a staple food in Ethiopia, consisting of two-thirds of their cereal diet, and is primarily used to make injera. Teff can also be combined with other baking flours to produce baked products, such as muffins and cookies. Teff has also been linked to other health benefits, such as anemia due to its high $\mathrm{Fe}$ content [4].

Most Ethiopian are comfortable with the taste of teff injera than any other food. Nutritionally teff is the most valuable grain in Ethiopia, which is considered an excellent source

*Corresponding author. E-mail: bscv2006@yahoo.com

This work is licensed under the Creative Commons Attribution 4.0 International License 
of fiber, $\mathrm{Fe}$, and $\mathrm{Ca}$ than other cereal grains. Recently there is a growing interest in teff grain utilization because of nutritional merits (whole grain) and free of the protein gluten that makes teff an increasingly important dietary component for individuals who suffer from gluten intolerance or celiac disease [5]. Teff is extremely exposed to soil contamination and complete removal of the extrinsic Fe from teff is not possible [6].

Teff is the smallest cereal grain with an average diameter of around $1 \mathrm{~mm}$ [7]. Teff grains are difficult to decorticate and the cereal is consumed as a wholegrain, improving nutrient intake for consumers. The color of teff can vary from white (ivory) to dark brown (black) depending on the variety. In Ethiopia, three major categories of teff can be identified, white (nech), red (quey) and mixed (sergegna). White teff generally grows only in the Ethiopian highlands and requires relatively good growing conditions. This along with its higher consumer preference may justify why white teff is the most expensive type of teff. However, in recent years red teff, which is believed to be more nutritious, is also gaining popularity among health-conscious consumers in Ethiopia.

Interest in teff has increased noticeably due to its very attractive nutritional profile and gluten-free nature of the grain, making it a suitable substitute for wheat and other cereals in their food applications as well as foods for people with celiac disease. Many gluten-free products may not meet the recommended daily intake for fiber, minerals, and vitamins [8].

Minerals are present in food at low but variable concentrations and forms. Minerals in food provide a reliable source of essential nutrients in a balanced and bio-available form. In cases where concentrations and bio-availabilities in the food supply are low, fortification is recommended [9]. The major health benefits and sources of essential minerals to humans are summarized in Table 1.

Table 1. Health benefits/main functions and sources of essential minerals.

\begin{tabular}{|l|l|l|c|}
\hline Mineral & \multicolumn{1}{|c|}{ Health benefit } & \multicolumn{1}{c|}{ Sources } & Reference \\
\hline Fe & $\begin{array}{l}\text { For red blood cells formation } \\
\text { and required for oxygen } \\
\text { transport throughout the body }\end{array}$ & $\begin{array}{l}\text { Seafood, meat, poultry or organ food like } \\
\text { liver, vegetables such as beans and peas, } \\
\text { nuts, seeds }\end{array}$ & {$[10]$} \\
\hline $\mathrm{Ca}$ & $\begin{array}{l}\text { For developing and } \\
\text { maintaining healthy bones and } \\
\text { teeth }\end{array}$ & $\begin{array}{l}\text { Milk and dairy products, a few green } \\
\text { vegetables, dried fruits, and drinking } \\
\text { water (including mineral water) }\end{array}$ & {$[11]$} \\
\hline $\begin{array}{l}\text { For digestion, metabolism, } \\
\text { reproduction, and wound } \\
\text { healing }\end{array}$ & $\begin{array}{l}\text { Wheat, brown rice, oats, lentils, soybeans, } \\
\text { dried peas, black-eyed peas, lima beans, } \\
\text { walnuts, peanuts, cashews, brazil nuts, } \\
\text { many cheeses, any kind of liver, and } \\
\text { animal flesh such as beef, lamb, chicken, } \\
\text { turkey, and various fish and seafood }\end{array}$ & {$[12]$} \\
\hline $\mathrm{Cu}$ & $\begin{array}{l}\text { To normal red blood cells } \\
\text { formation and connective } \\
\text { tissue formation }\end{array}$ & $\begin{array}{l}\text { Wheat, barley, sunflower seeds, almonds, } \\
\text { pecans, walnuts, peanuts, cashews, } \\
\text { prunes, raisins apricots, various dried } \\
\text { beans, mushrooms, chicken, and most fish }\end{array}$ & {$[12]$} \\
\hline $\mathrm{Mn}$ & $\begin{array}{l}\text { Support brain function and } \\
\text { required for blood sugar } \\
\text { regulation }\end{array}$ & $\begin{array}{l}\text { Surface water and groundwater, foods, } \\
\text { tea, green vegetables, nuts, bread and } \\
\text { other cereals }\end{array}$ & {$[12]$} \\
\hline
\end{tabular}

The mineral contamination of teff is probably due to its small size and suggests increased contact with soil over a larger area [13]. The contamination of cereal grains in Ethiopia, particularly in teff has often been associated with traditional methods of threshing grain under the hooves of cattle. Traditional threshing led to a $30-38 \%$ increase in Fe content, mainly due to soil contamination [13]. 
Aluminum is released to the environment both by natural processes and from anthropogenic sources. Mobilization of Al through human actions is mostly indirect and occurs as a result of the emission of acidifying substances to the atmosphere [14]. Al and its compounds appear to be poorly absorbed in humans. Cadmium is highly toxic to humans. $\mathrm{Cd}$ is a relatively rare element, released to the air, land, and water by human activities. In general, the two major sources of contamination are the production and utilization of $\mathrm{Cd}$ and the disposal of wastes containing $\mathrm{Cd}$. $\mathrm{Pb}$ is a classical chronic or cumulative poison. In humans, $\mathrm{Pb}$ can result in a wide range of biological effects depending upon the level and duration of exposure.

It is generally accepted that teff grain is highly nutritious, although there is some debate about the precise nutritional value of it [1]. Some authors have estimated that teff has high level of iron content but others reflect this high level is attributed to the dust and dirt that cling to the teff grain [1]. In comparison, other studies revealed that Fe content of teff varies between geographical regions, possibly as a result of soil contamination $[15,16]$. The results reported in the literature are controversial and have differences; this may be due to sampling error. Most of the researches were done by collecting teff flour samples from commercially available mill houses; this may increases the contamination levels of the samples [15, 16].

Furthermore, $\mathrm{Al}$ and $\mathrm{Cd}$ contents of teff have not reported in most of the literature. There is only one report on the Al and Cd levels in the teff grain [14]. Since teff is one of the major and indigenous cereal crops in Ethiopia, identifying the metal contents (including $\mathrm{Al}$ and $\mathrm{Cd}$ ) in it is very important. While the Amhara province is one of the teff growing regions in the country [17], there is no reported literature about the levels of metals in teff samples collected from the selected Amhara region. Hence collecting teff grain samples from Amhara region and determining its mineral contents is very important. Therefore, the objective of present study was to determine the selected metal contents in teff samples collected from three different areas of Amhara region of Ethiopia by using microwave plasma-atomic emission spectrometry (MPAES) and to compare the results of the metal contents in teff samples with the reported values in the literature.

\section{EXPERIMENTAL}

\section{Chemicals and reagents}

The reagents $\mathrm{HClO}_{4}(70 \%)$ and $\mathrm{HNO}_{3}(69-72 \%)$ (Sigma Aldrich Steinleim, Germany) were used for the digestion of samples. The reference standards of the metals were the products of Perkin Elmer (Boston, USA). The standard stock solution $\left(1000 \mathrm{mg} \mathrm{L}^{-1}\right)$ was prepared from the nitrate salts of the metals. The working standard solutions of the metals were prepared freshly from the stock standard solutions.

\section{Apparatus and instrument}

A ceramic mortar and pestle (USA) were used for grinding and homogenizing the samples. A digital analytical balance (with $0.1 \mathrm{mg}$ precision) was used for weighing the samples. A Kjeldahl digestion block (Gallenkamp, England) was used for the digestion of samples. A microwave-induced plasma (MP) interfaced to an atomic emission spectrophotometer (AES) (Agilent 4200 MP-AES, USA) with nitrogen supplied from an Agilent 4107 nitrogen generator was used for the determination of metals.

\section{Sampling site description}

Samples were collected from the most teff producing areas of (Bahir Dar, Debre Markos and Bure) of the Amhara regional state, of Ethiopia. Bahir Dar is located at a latitude of 
$11^{\circ} 35^{\prime} 37.1^{\prime \prime} \mathrm{N}$ and longitude of $37^{\circ} 23^{\prime} 26.8^{\prime \prime} \mathrm{E}$ in the northern hemisphere. It is located at the exit of the Abbay (Blue Nile) River from Lake Tana at an altitude of 1,820 meters above sea level. The city is approximately $578 \mathrm{~km}$ the north-west of Addis Ababa. Debre Markos is a city in the north-west of Ethiopia. It is located at a latitude and longitude of $10^{\circ} 20^{\prime} \mathrm{N}$ and $37^{\circ} 43^{\prime} \mathrm{E}$ coordinates and an elevation of 2,446 meters above sea level. Debre Markos is approximately $306 \mathrm{~km}$ from Addis Ababa. Bure is a town in western Ethiopia located in the Mirab Gojjam Zone of the Amhara region. It is located at a latitude and longitude of $10^{\circ} 42^{\prime} \mathrm{N}$ and $37^{\circ} 4^{\prime} \mathrm{E}$ with an elevation of 2091 meters above sea level. Bure is approximately $414 \mathrm{~km}$ from Addis Ababa. The study areas were selected based on their higher production of teff and consumption. The study areas were also selected with the consideration of the variation in their soil chemical composition since the soil elemental composition affects the mineral uptake of plants [18].

\section{Sample collection and preparation}

White, red, and mixed varieties of teff samples were collected from the north-western areas of Ethiopia (Bahir Dar, Debre Markos, and Bure), which are the most teff producing areas. From each sample type, around $0.1 \mathrm{~kg}$ of sub-samples were collected from five different local shops after confirming the original places from where the sample came from. A total of around $0.5 \mathrm{~kg}$ of composite teff samples were collected for each of the three teff varieties. The collected samples were kept in clean polyethylene bags and transported to the laboratory. The soil and stone particles in the teff samples were removed. The samples were washed with tap water and then with distilled water to remove adsorbed dust and particulate matters. The samples were then air-dried for seven days to remove moisture. The dried samples were ground by using a grinder and sieved to mesh size of $0.5 \mathrm{~mm}$. The powdered samples were stored in clean and dried plastic bags (polyethylene) under airtight conditions until the time of digestion.

\section{Optimization of digestion procedure}

Wet acid digestion is one of the methods widely used to get free metal ions in dissolved form from complex organic matrix based on changing different digestion parameters, like volume ratio of reagents added, digestion temperature, and time. The digestion is assumed to be complete if the solution is clear and colorless.

Different digestion procedures were carried out for the teff samples using $\mathrm{HNO}_{3}$ and $\mathrm{HClO}_{4}$ acid mixtures by varying volume of the acid mixture, digestion time and digestion temperature [19]. The results are summarized in Table 2. Optimized procedures were selected based on the usage of lesser reagent volume, shorter digestion time and reasonable mild temperature for obtaining clear and colorless solutions of the resulting digests. Based on this fact, the optimized digestion conditions for the teff samples in this study were $\left(5 \mathrm{~mL} \mathrm{HNO}_{3}: 1 \mathrm{~mL} \mathrm{HClO}_{4}\right)$ volume ratio of reagents, $240{ }^{\circ} \mathrm{C}$ digestion temperature, and 2:30 $\mathrm{h}$ digestion time.

\section{Digestion of samples}

Applying the optimized conditions, $0.5 \mathrm{~g}$ of powdered teff sample was transferred into a $100 \mathrm{~mL}$ round bottom flask. Then $6 \mathrm{~mL}$ of a mixture of $\mathrm{HNO}_{3}(69-72 \%)$ and $\mathrm{HClO}_{4}(70 \%)$ with a volume ratio of 5:1 (v/v) was added and the mixture was digested on a Kjeldahl digestion apparatus fitted with a reflux condenser by setting the temperature at $240{ }^{\circ} \mathrm{C}$ and digested for 2:30 $\mathrm{h}$. The digest was allowed to cool to room temperature for $10 \mathrm{~min}$ without dismantling the condenser and for $10 \mathrm{~min}$ after removing the condenser. To the cooled solution, $10 \mathrm{~mL}$ of distilled water was added to dissolve the precipitate formed on cooling, and to minimize dissolution of filter paper by the digested residue while filtering with filter paper (Whatman 125 $\mathrm{mm}$ diameter, Germany) into $50 \mathrm{~mL}$ volumetric flask. The round bottom flask was rinsed 
subsequently with around $5 \mathrm{~mL}$ distilled water until the total volume reached around $40 \mathrm{~mL}$. Then finally, the solution was filled to the mark $(50 \mathrm{~mL})$ using distilled water. The digestion was carried out in triplicate for each sample. Digestion of the blank was also performed in parallel with the teff samples keeping all digestion parameters the same. The metal concentrations in the digested sample solutions were determined by using MP-AES.

Table 2. Reagent ratios and volumes, temperature and time attempted during optimization of digestion of $0.5 \mathrm{~g}$ of teff sample.

\begin{tabular}{|c|c|c|c|c|c|c|}
\hline \multirow[b]{2}{*}{ Trials } & \multicolumn{3}{|c|}{ Reagent volume (mL) } & \multirow{2}{*}{$\begin{array}{c}\text { Temperature } \\
\left({ }^{\circ} \mathrm{C}\right)\end{array}$} & \multirow{2}{*}{$\begin{array}{l}\text { Time } \\
\text { (h) }\end{array}$} & \multirow[b]{2}{*}{ Results } \\
\hline & $\mathrm{HNO}_{3}$ & $\mathrm{HClO}_{4}$ & Total & & & \\
\hline 1 & 1 & 1 & 2 & 240 & $2: 30$ & Yellow with suspension \\
\hline 2 & 2 & 1 & 3 & 240 & $2: 30$ & Cloudy yellow \\
\hline 3 & 3 & 1 & 4 & 240 & $2: 30$ & Nearly colorless \\
\hline 4 & 4 & 1 & 5 & 240 & $2: 30$ & Slightly colorless \\
\hline 5 & 5 & 1 & 6 & 240 & $2: 30$ & Clear colorless* \\
\hline 6 & 6 & 1 & 7 & 240 & $2: 30$ & Clear colorless \\
\hline 7 & 3 & 2 & 5 & 240 & $2: 30$ & Slightly colorless \\
\hline 8 & 4 & 2 & 6 & 240 & $2: 30$ & Nearly colorless \\
\hline 9 & 4 & 1 & 5 & 240 & $2: 30$ & Nearly colorless \\
\hline 10 & 5 & 2 & 7 & 240 & $2: 30$ & Clear colorless \\
\hline 11 & 5 & 1 & 6 & 240 & $0: 30$ & Yellow with suspension \\
\hline 12 & 5 & 1 & 6 & 240 & $1: 00$ & Yellow with suspension \\
\hline 13 & 5 & 1 & 6 & 240 & $1: 30$ & Cloudy light yellow \\
\hline 14 & 5 & 1 & 6 & 240 & 2:00 & Light yellow \\
\hline 15 & 5 & 1 & 6 & 240 & $2: 30$ & Clear colorless* \\
\hline 16 & 5 & 1 & 6 & 240 & $3: 00$ & Clear colorless \\
\hline 17 & 5 & 1 & 6 & 150 & $2: 30$ & Cloudy yellow with suspension \\
\hline 18 & 5 & 1 & 6 & 180 & $2: 30$ & Cloudy yellow with suspension \\
\hline 19 & 5 & 1 & 6 & 210 & $2: 30$ & Slightly yellow \\
\hline 20 & 5 & 1 & 6 & 240 & $2: 30$ & Clear colorless* \\
\hline 21 & 5 & 1 & 6 & 270 & $2: 30$ & Clear colorless \\
\hline 22 & 5 & 1 & 6 & 300 & $2: 30$ & Clear colorless \\
\hline
\end{tabular}

*The optimized conditions for the three parameters (reagents volume ratio, time and temperature).

\section{Instrument calibration}

Calibration standard solutions were prepared for each of the metals from the MP-AES standard stock solutions that contained $1000 \mathrm{mg} \mathrm{L}^{-1}$. Intermediate standards were used to obtain five working standards for each metal of interest. Then $\mathrm{Fe}, \mathrm{Ca}, \mathrm{Cu}, \mathrm{Zn}, \mathrm{Mn}, \mathrm{Al}, \mathrm{Cd}$ and $\mathrm{Pb}$ were determined by MP-AES. The correlation coefficient for each metal showed that the change in emission with concentration is in good correlation. Five-points calibration curve were established by running a series of the prepared working standard solutions for each metal. After calibration the sample solutions were aspirated into the MP-AES instrument, and the elemental concentrations were determined. Three replicate determinations were carried out on each sample for each metal. The same analytical procedure was employed for the determination of elements in the digested blank solutions. 


\section{Method detection and quantification limits}

For determining the limit of detection of the analytical method (LOD), triplicate of eight blanks were prepared in parallel and analyzed for their metal contents. The standard deviation (SD) of the eight blanks was calculated and multiplied by three $\left(\mathrm{LOD}=3 \mathrm{SD}_{\mathrm{b}}\right)$ to determine the method detection limit. The limit of quantification (LOQ) is the smallest quantity of analyte that can be measured with acceptable accuracy and precision and it is described as ten times the standard deviation of the blank. The method detection limits were found to be low enough $(\leq 0.5 \mathrm{mg} / \mathrm{kg})$ to determine the metals in the samples at trace levels. The calibration curves were with good correlation coefficients. The wavelength, method detection, and quantification limit, correlation coefficient, and calibration curve equations are given in Table 3.

Table 3. The wavelength, method detection and quantification limit, correlation coefficient and calibration curve equations.

\begin{tabular}{|c|c|c|c|c|c|}
\hline Metal & $\begin{array}{c}\text { Wavelength } \\
(\mathrm{nm})\end{array}$ & $\begin{array}{c}\mathrm{MDL}^{1} \\
(\mathrm{mg} / \mathrm{kg})\end{array}$ & $\mathrm{MQL}^{2}(\mathrm{mg} / \mathrm{kg})$ & $\begin{array}{c}\text { Correlation } \\
\text { coefficient }\end{array}$ & $\begin{array}{c}\text { Calibration curve } \\
\text { equation* }\end{array}$ \\
\hline $\mathrm{Fe}$ & 372.0 & 0.40 & 1.30 & 0.9999 & $\mathrm{I}=5032 \mathrm{C}+81.40$ \\
\hline $\mathrm{Ca}$ & 422.7 & 0.46 & 1.90 & 0.9992 & $\mathrm{I}=68218 \mathrm{C}+8746.00$ \\
\hline $\mathrm{Cu}$ & 324.8 & 0.40 & 1.30 & 0.9998 & $\mathrm{I}=10654 \mathrm{C}+9283.00$ \\
\hline $\mathrm{Zn}$ & 213.9 & 0.22 & 0.70 & 0.9990 & $\mathrm{I}=2448 \mathrm{C}-198.70$ \\
\hline $\mathrm{Mn}$ & 403.1 & 0.15 & 0.50 & 0.9999 & $\mathrm{I}=27752 \mathrm{C}-255.50$ \\
\hline $\mathrm{Al}$ & 396.1 & 0.17 & 0.50 & 0.9990 & $\mathrm{I}=17002 \mathrm{C}-25.00$ \\
\hline $\mathrm{Cd}$ & 228.8 & 0.02 & 0.10 & 0.9996 & $\mathrm{I}=7863 \mathrm{C}+733.90$ \\
\hline $\mathrm{Pb}$ & 405.8 & 0.06 & 0.20 & 0.9997 & $\mathrm{I}=2889 \mathrm{C}+11.22$ \\
\hline
\end{tabular}

*I is the emission intensity and $\mathrm{C}$ is the concentration. ${ }^{1}$ Method detection limit, ${ }^{2}$ Method quantification limit.

\section{Method validation}

Recovery is one of the most used techniques utilized for validation of the analytical results and evaluating how far the method is acceptable for its intended purpose. The validity of the digestion procedures for the elements $\mathrm{Fe}, \mathrm{Ca}, \mathrm{Zn}, \mathrm{Cu}, \mathrm{Pb}$ and $\mathrm{Cd}$ was assured by spiking the samples with a standard solution of known concentration of the target analytes and the percentage recoveries lies within the range $92-104 \%$, which are within the acceptable range. The results are summarized in Table 4.

Table 4. Analytical results of recovery test of teff sample.

\begin{tabular}{|c|l|c|l|l|l|}
\hline Metal & $\begin{array}{l}\text { Concentration in } \\
\text { sample }(\mathrm{mg} / \mathrm{kg})\end{array}$ & \% Spiking & $\begin{array}{l}\text { Amount added } \\
(\mathrm{mg} / \mathrm{kg})\end{array}$ & $\begin{array}{l}\text { Spiked sample } \\
(\mathrm{mg} / \mathrm{kg})\end{array}$ & Recovery $(\%)$ \\
\hline $\mathrm{Fe}$ & $1195 \pm 1.0$ & 20 & 239 & $1417 \pm 0.8$ & $93 \pm 4.0$ \\
\hline $\mathrm{Ca}$ & $348 \pm 0.5$ & 25 & 87 & $428 \pm 2.0$ & $92 \pm 3.0$ \\
\hline $\mathrm{Cu}$ & $15 \pm 0.4$ & 40 & 6 & $20.7 \pm 0.3$ & $95 \pm 0.5$ \\
\hline $\mathrm{Zn}$ & $102 \pm 2.0$ & 30 & 30.6 & $132 \pm 1.0$ & $98 \pm 0.6$ \\
\hline $\mathrm{Cd}$ & $1.8 \pm 0.1$ & 50 & 0.9 & $2.73 \pm 0.1$ & $103 \pm 1.0$ \\
\hline $\mathrm{Pb}$ & $2.8 \pm 0.1$ & 45 & 1.26 & $4.11 \pm 0.5$ & $104 \pm 2.0$ \\
\hline
\end{tabular}

\section{Statistical analysis}

The correlation among physicochemical parameters was assessed by Pearson correlation methods using a statistical software (SPSS Version 21). Besides, the graphical expression was done using Microsoft excel 7 in addition to arrangements of different data sets. 


\section{RESULTS AND DISCUSSION}

\section{Concentrations of metals in teff samples}

The concentrations of metals in the three varieties of the teff samples are given in Table 5. Mean values were determined from triplicate analysis of each sample.

The range of concentration of $\mathrm{Al}, \mathrm{Fe}, \mathrm{Ca}, \mathrm{Zn}, \mathrm{Mn}, \mathrm{Cu}, \mathrm{Pb}$, and $\mathrm{Cd}$ in the three varieties of teff samples from the three sites were 713-1513, 252-1195, 233-348, 69-102, 20-45, 13-15, 1.82.8 and $0.8-1.8 \mathrm{mg} / \mathrm{kg}$, respectively. The concentrations of the metals showed that the white teff samples collected from the Bure site have higher amounts of $\mathrm{Fe}, \mathrm{Ca}, \mathrm{Cu}, \mathrm{Al}$, and $\mathrm{Cd}$ compared to that of the red and mixed teff samples. The red teff samples collected from Debre Markos has higher amounts of $\mathrm{Fe}, \mathrm{Zn}, \mathrm{Mn}, \mathrm{Al}$, and $\mathrm{Pb}$ compared to that of the white and mixed teff samples. Similarly, the red teff samples collected from Bahir Dar have higher amounts of $\mathrm{Fe}, \mathrm{Ca}, \mathrm{Cu}, \mathrm{Zn}$, $\mathrm{Mn}, \mathrm{Al}$, and $\mathrm{Pb}$ compared to that of the white and mixed teff samples. The level of $\mathrm{Al}$ is not reported in the literature. In this study $\mathrm{Al}$ was determined in the teff samples for the first time.

$\mathrm{Cd}$ is highly toxic to humans. In this study, $\mathrm{Cd}$ was detected in the teff samples at a trace level $(0.8-1.8 \mathrm{mg} / \mathrm{kg})$. $\mathrm{Pb}$ is another toxic metal to humans. $\mathrm{Pb}$ was also detected in the teff samples at a trace level $(1.8-2.8 \mathrm{mg} / \mathrm{kg})$. The presence $\mathrm{Cd}$ and $\mathrm{Pb}$ at the trace levels in the teff samples is not desirable and hence it undermines the nutritional values of the teff to some extent.

Table 5. Mean concentrations (mean $\pm \mathrm{SD}, \mathrm{n}=3, \mathrm{mg} \mathrm{kg}^{-1}$ dry weight) of metals in each sample sites analyzed by MP-AES.

\begin{tabular}{|l|l|l|l|l|l|l|l|l|l|}
\hline \multirow{3}{*}{ Metal } & \multicolumn{8}{|c|}{ Concentration (mg/kg) (mean \pm SD) of metals in samples from } \\
\cline { 2 - 11 } & \multicolumn{3}{|c|}{ Bure } & \multicolumn{3}{|c|}{ Debre Markos } & \multicolumn{3}{|c|}{ Bahir Dar } \\
\cline { 2 - 11 } & White & Red & Mixed & White & Red & Mixed & White & Red & Mixed \\
\hline $\mathrm{Fe}$ & $1195 \pm 1$ & $709 \pm 1$ & $252 \pm 2$ & $485 \pm 1$ & $1110 \pm 2$ & $588 \pm 3$ & $645 \pm 1$ & $664 \pm 2$ & $694 \pm 4$ \\
\hline $\mathrm{Ca}$ & $348 \pm 0.5$ & $233 \pm 2$ & $286 \pm 5$ & $266 \pm 1$ & $248 \pm 1$ & $253 \pm 9$ & $247 \pm 1$ & $297 \pm 0.2$ & $265 \pm 1$ \\
\hline $\mathrm{Cu}$ & $15 \pm 0.4^{\mathrm{b}}$ & $13 \pm 0.2$ & $13 \pm 1$ & $13 \pm 0^{\mathrm{b}}$ & $13 \pm 0.1$ & $13 \pm 1$ & $13 \pm 1^{\mathrm{b}}$ & $14 \pm 0.3$ & $13 \pm 0.2$ \\
\hline $\mathrm{Zn}$ & $80 \pm 1$ & $90 \pm 1$ & $87 \pm 3$ & $85 \pm 1$ & $102 \pm 2$ & $73 \pm 3$ & $73 \pm 1$ & $77 \pm 1$ & $69 \pm 3$ \\
\hline $\mathrm{Mn}$ & $20 \pm 0.4^{\mathrm{a}}$ & $42 \pm 2^{\mathrm{c}}$ & $36 \pm 3$ & $21 \pm 0.5^{\mathrm{a}}$ & $41 \pm 0.6^{\mathrm{c}}$ & $24 \pm 2$ & $28 \pm 2^{\mathrm{a}}$ & $45 \pm 1^{\mathrm{c}}$ & $36 \pm 2$ \\
\hline $\mathrm{Al}$ & $1232 \pm 2$ & $786 \pm 1$ & $713 \pm 2$ & $792 \pm 2$ & $1341 \pm 2$ & $752 \pm 8$ & $779 \pm 1$ & $1513 \pm 2$ & $832 \pm 4$ \\
\hline $\mathrm{Cd}$ & $0.8 \pm 0$ & $0.8 \pm 0.1$ & $1.8 \pm 0.2^{\mathrm{d}}$ & $0.8 \pm 0$ & $0.8 \pm 0.1$ & $1.8 \pm 0.2^{\mathrm{d}}$ & $1.8 \pm 0.1$ & $1.8 \pm 0.2$ & $1.8 \pm 0.2^{\mathrm{d}}$ \\
\hline $\mathrm{Pb}$ & $1.8 \pm 0$ & $1.8 \pm 0.1$ & $2.8 \pm 0.3^{\mathrm{d}}$ & $1.8 \pm 0$ & $1.8 \pm 0.1$ & $2.8 \pm 0.1^{\mathrm{d}}$ & $1.8 \pm 0.1$ & $1.8 \pm 0.1$ & $1.8 \pm 0.1^{\mathrm{d}}$ \\
\hline
\end{tabular}

The same letter indicated that the values were not significantly different at $\mathrm{p}<0.05$, according to Duncan's multiple range test.

As can be seen in Table 5, higher concentrations of $\mathrm{Al}$ and $\mathrm{Fe}$ are observed in the white teff samples collected from the Bure sampling site, and relatively lower concentration of $\mathrm{Zn}$ is observed compared to that of $\mathrm{Al}, \mathrm{Fe}$, and Ca collected from the three sampling sites. Similarly, a relatively higher concentration of $\mathrm{Mn}$ and $\mathrm{Cu}$ are observed compared to that of $\mathrm{Pb}$ and $\mathrm{Cd}$ in the white teff samples collected from the three sampling areas. The mean concentrations of the metals $(\mathrm{mg} / \mathrm{kg})$ in the white teff samples collected from the three sampling areas can be arranged in the order: $\mathrm{Al}>\mathrm{Fe}>\mathrm{Ca}>\mathrm{Zn}>\mathrm{Mn}>\mathrm{Cu}>\mathrm{Pb}>\mathrm{Cd}$.

Relatively higher concentrations of $\mathrm{Mn}$ and $\mathrm{Cu}$ are observed compared to that of $\mathrm{Pb}$ and $\mathrm{Cd}$ in the red teff samples collected from the three sampling areas. Similarly, higher concentrations of $\mathrm{Al}$ and $\mathrm{Fe}$ are observed in the red teff samples collected from Debre Markos and Bahir Dar sampling sites, and relatively lower concentration of $\mathrm{Zn}$ is observed compared to that of $\mathrm{Al}, \mathrm{Fe}$, and $\mathrm{Ca}$ collected from the three sampling sites. The mean concentrations of the metals $(\mathrm{mg} / \mathrm{kg})$ in the red teff samples collected from the three sampling sites can be arranged in order: $\mathrm{Al}>\mathrm{Fe}$ 
$>\mathrm{Ca}>\mathrm{Zn}>\mathrm{Mn}>\mathrm{Cu}>\mathrm{Pb}>\mathrm{Cd}$. Higher concentrations of $\mathrm{Al}$ and $\mathrm{Fe}$ are observed in the mixed teff samples collected from the Bahir Dar and Debre Markos sampling sites, and relatively lower concentration of $\mathrm{Zn}$ is observed compared to that of $\mathrm{Al}, \mathrm{Fe}$, and $\mathrm{Ca}$ collected from the three sampling sites. Similarly, relatively higher concentrations of $\mathrm{Mn}$ and $\mathrm{Cu}$ are observed compared to that of $\mathrm{Pb}$ and $\mathrm{Cd}$ in the mixed teff samples collected from the three sampling areas. The mean concentrations of the metals $(\mathrm{mg} / \mathrm{kg})$ in the mixed teff samples collected from the three sampling areas can be arranged in the order: $\mathrm{Al}>\mathrm{Fe}>\mathrm{Ca}>\mathrm{Zn}>\mathrm{Mn}>\mathrm{Cu}>\mathrm{Pb}>\mathrm{Cd}$.

The overall mean concentrations of the metals $(\mathrm{mg} / \mathrm{kg})$ in the white, red, and mixed teff samples collected from the three sampling sites can be arranged in the order: $\mathrm{Al}>\mathrm{Fe}>\mathrm{Ca}>\mathrm{Zn}$ $>\mathrm{Mn}>\mathrm{Cu}>\mathrm{Pb}>\mathrm{Cd}$ (Figure 1). There is a significant difference in the mean concentrations of the metals $\mathrm{Al}, \mathrm{Fe}, \mathrm{Ca}$, and $\mathrm{Mn}$ between the white, red and mixed varieties of teff samples. While only small variations of the mean concentrations of $\mathrm{Cu}, \mathrm{Pb}$ and $\mathrm{Cd}$ are observed between the white, red and mixed varieties of teff samples collected from the three sampling sites.

Higher mean concentrations of $\mathrm{Al}$ and $\mathrm{Fe}$ are observed in the teff samples collected from the three sampling sites, and a relatively lower amount of $\mathrm{Zn}$ is observed compared to that of $\mathrm{Al}, \mathrm{Fe}$, and $\mathrm{Ca}$ collected from the three sampling sites. Similarly, relatively higher mean concentrations of $\mathrm{Mn}$ and $\mathrm{Cu}$ are observed compared to that of $\mathrm{Pb}$ and $\mathrm{Cd}$ in the teff samples collected from the three sampling areas. The overall mean concentrations of the metals $(\mathrm{mg} / \mathrm{kg})$ in the teff samples collected from the three sampling areas can be arranged in the order: $\mathrm{Al}>\mathrm{Fe}>\mathrm{Ca}>\mathrm{Zn}>\mathrm{Mn}>$ $\mathrm{Cu}>\mathrm{Pb}>\mathrm{Cd}$.
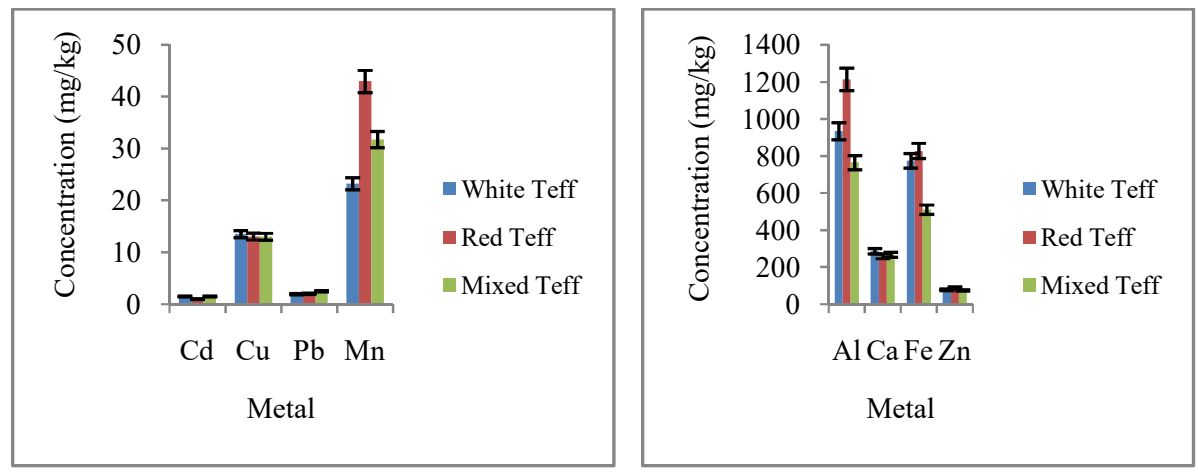

Figure 1. The overall mean concentrations of the metals determined by MP-AES in the teff samples collected from the three sampling sites.

Comparisons of the metal contents in teff samples with reported values

Different analytical methods were used to determine the amounts of elements in teff samples by different researchers. The results of the present study are compared with reported values (Table 6).

The Fe contents determined in teff samples in this study are higher than most of the other reported values (Table 6) and it is within the range of study by Baye et al. [13]. The amount of $\mathrm{Ca}$ determined in this study is relatively lower than the other reported values. Cd is not reported in most of the studies, except one study using ICP-MS which reported $3.00 \mathrm{mg} / \mathrm{kg}$ in white teff and $5.00 \mathrm{mg} / \mathrm{kg}$ in red teff [14]. Cd is also detected in this study in the range $0.8-1.8 \mathrm{mg} / \mathrm{kg}$, which are much lower than the reported values $(3.00-5.00 \mathrm{mg} / \mathrm{kg})$ by ICP-MS method [14]. The amount of $\mathrm{Cu}$ determined in this study is similar to the other reported values. The amount of $\mathrm{Pb}$ in teff is also determined by Kibatu et al. [2] and by the ICP-MS method [14] and the values are smaller than the detected values in this study. The Mn determined in this study is lower than the 
reported values of the other studies. The amount of $\mathrm{Zn}$ determined in this study is higher than the reported values. Al content in teff (20.8-24.2 mg/kg) has been reported in only one study [14]. Al is also determined in this study and its values are found much higher in the present study. Its concentration is not reported by other researchers.

Table 6. Comparison of metals concentration ( $\mathrm{mg} / \mathrm{kg}$, dry mass) of teff with reported values.

\begin{tabular}{|l|l|l|l|l|l|l|}
\hline \multirow{2}{*}{$\begin{array}{l}\text { Teff } \\
\text { variety }\end{array}$} & \multicolumn{4}{|c|}{ Metals concentration $(\mathrm{mg} / \mathrm{kg})$} & Method & \multirow{2}{*}{ Reference } \\
\cline { 2 - 5 } White & Fe & $\mathrm{Ca}$ & $\mathrm{Zn}$ & $\mathrm{Al}$ & & \\
\hline White & 11.4 & $170-1240$ & $24-68$ & - & FAAS & {$[13]$} \\
\hline White & $160 \pm 2$ & $1807 \pm 15$ & 3.58 & 20.8 & ICP-MS & {$[14]$} \\
\hline White & 189 & 1560 & - & - & FAAS & {$[20]$} \\
\hline White & $161 \pm 2$ & $839 \pm 1$ & $27 \pm 0.0$ & - & FAAS & {$[8]$} \\
\hline White & $90-146$ & - & - & - & PTXRF & {$[2]$} \\
\hline White & $\mathbf{4 8 5 - 1 1 9 5}$ & $\mathbf{2 4 7 - 3 4 8}$ & $\mathbf{7 3 - 8 5}$ & $\mathbf{7 8 0 - 1 2 3 2}$ & MP-AES & This study \\
\hline Red & $116-1500$ & $180-1780$ & $23-67$ & - & FAAS & {$[13]$} \\
\hline Red & $246 \pm 1$ & $1785 \pm 10$ & $48 \pm 11$ & - & FAAS & {$[20]$} \\
\hline Red & 14.2 & 444 & 8.71 & 24.2 & ICP-MS & {$[14]$} \\
\hline Red & $\mathbf{6 6 4 - 1 1 1 0}$ & $\mathbf{2 3 3 - 2 9 7}$ & $\mathbf{7 7 - 1 0 2}$ & $\mathbf{7 8 6 - 1 5 1 3}$ & MP-AES & This study \\
\hline Mixed & $115-1500$ & $788-1470$ & $38-39$ & - & FAAS & {$[13]$} \\
\hline Mixed & $201 \pm 1$ & $1686 \pm 11$ & $38 \pm 0.1$ & - & FAAS & {$[20]$} \\
\hline Mixed & 589 & 1570 & - & - & FAAS & {$[8]$} \\
\hline Mixed & $226 \pm 0.02$ & $1162 \pm 0.3$ & $34 \pm 0.1$ & - & PTXRF & {$[2]$} \\
\hline Mixed & 76 & 1800 & 36 & - & FAAS & {$[22]$} \\
\hline Mixed & $\mathbf{2 5 2 - 6 9 4}$ & $\mathbf{2 5 3 - 2 8 6}$ & $\mathbf{6 9 - 8 7}$ & $\mathbf{7 1 3 - 8 3 2}$ & MP-AES & This study \\
\hline Teff type & Cd & Pb & Cu & Mn & Method & Reference \\
\hline White & - & - & $25-53$ & & FAAS & {$[13]$} \\
\hline White & 3.00 & 0.04 & 1.65 & 12 & ICP-MS & {$[14]$} \\
\hline White & - & - & $11 \pm 0.1$ & $48 \pm 0.04$ & FAAS & {$[20]$} \\
\hline White & - & - & - & - & - & {$[8]$} \\
\hline White & - & $1 \pm 0.0$ & $4 \pm 0.03$ & - & PTXRF & {$[2]$} \\
\hline White & - & - & - & - & - & {$[16]$} \\
\hline White & $\mathbf{0 . 8 - 1 . 8}$ & $\mathbf{1 . 8 - 2 . 0}$ & $\mathbf{1 3 - 1 5}$ & $\mathbf{2 0 - 2 8}$ & MP-AES & This study \\
\hline Red & - & - & $11-36$ & - & FAAS & {$[13]$} \\
\hline Red & 5.00 & 0.05 & 1.64 & 38 & ICP-MS & {$[14]$} \\
\hline Red & - & - & $25 \pm 0.3$ & $224 \pm 0.2$ & FAAS & {$[20]$} \\
\hline Red & $\mathbf{0 . 8 4 - 1 . 3}$ & $\mathbf{1 . 8 - 2 . 0}$ & $\mathbf{1 3 - 1 4}$ & $\mathbf{4 1 - 4 5}$ & MP-AES & This study \\
\hline Mixed & - & - & 16 & - & FAAS & {$[13]$} \\
\hline Mixed & - & - & $38 \pm 0.1$ & $133 \pm 0.0$ & FAAS & {$[20]$} \\
\hline Mixed & - & - & - & - & - & {$[8]$} \\
\hline Mixed & - & $1 \pm 0.0$ & $4 \pm 0.01$ & - & PTXRF & {$[2]$} \\
\hline Mixed & - & - & - & - & - & {$[22]$} \\
\hline Mixed & $\mathbf{0 . 8 - 1 . 8}$ & $\mathbf{1 . 8 - 2 . 8}$ & $\mathbf{1 2 . 8 - 1 3}$ & $\mathbf{2 4 - 3 6}$ & MP-AES & This study \\
\hline & & & & & & \\
\hline
\end{tabular}

Comparison of levels of metals in teff with other cereals

As can be seen from Table 7, diversified concentration ranges of the studied metals were noticed compared with other cereals like maize, sorghum, wheat and rice. Between teff and wheat, teff and rice, comparable $\mathrm{Ca}$ concentrations are observed and between teff and maize comparable $\mathrm{Cu}$ concentrations are occurred. For the other metals, higher concentrations in teff, maize, sorghum, wheat, and rice with significant differences have been noticed. This variation is may be due to species variability and variations in agricultural practices. The results obtained in this study 
indicated that teff contains higher amounts of $\mathrm{Fe}, \mathrm{Cu}$, and $\mathrm{Zn}$ than cereals like sorghum, wheat, and rice. On the other hand, $\mathrm{Ca}$ is higher in teff than maize and sorghum, and $\mathrm{Ca}$ in teff is comparable with wheat, $\mathrm{Cu}$ in teff is comparable with maize.

Table 7. Comparison of metal contents of teff grain compared to other cereals $(\mathrm{mg} / \mathrm{kg})$.

\begin{tabular}{|c|c|c|c|c|c|c|}
\hline \multirow[t]{2}{*}{ Cereals } & \multicolumn{4}{|c|}{ Metal concentrations $(\mathrm{mg} / \mathrm{kg})$} & \multirow[t]{2}{*}{ Method } & \multirow[t]{2}{*}{ Reference } \\
\hline & $\mathrm{Fe}$ & $\mathrm{Ca}$ & $\mathrm{Cu}$ & $\mathrm{Zn}$ & & \\
\hline White teff & $95-377$ & $170-1240$ & $25-53$ & $24-68$ & FAAS & {$[23]$} \\
\hline Red teff & $116-1500$ & $180-1780$ & $11-36$ & $23-67$ & FAAS & {$[24]$} \\
\hline $\begin{array}{l}\text { Mixed } \\
\text { teff }\end{array}$ & $115-1500$ & $788-1470$ & 16 & $38-39$ & FAAS & {$[20]$} \\
\hline Maize & $36-48$ & 160 & 13 & $26-46$ & FAAS & {$[13]$} \\
\hline Maize & $18-115$ & $66.5-104$ & $0.04-1.32$ & $61.7-77.6$ & GF- & {$[25]$} \\
\hline Sourghum & $35-41$ & $50-58$ & 4.1 & $14-17$ & $\begin{array}{l}\text { AAS } \\
\text { FAAS }\end{array}$ & {$[20]$} \\
\hline Wheat & 37 & $152-395$ & 2.3 & 17 & FAAS & {$[23]$} \\
\hline Rice & 15 & 230 & 1.6 & 22 & FAAS & [13] \\
\hline Rice & 41-113 & $198-427$ & $3.3-15$ & $17-140$ & FAAS & {$[26]$} \\
\hline White teff & $485-1195$ & $247-348$ & $13-15$ & $73-85$ & $\begin{array}{l}\text { MP- } \\
\text { AES }\end{array}$ & $\begin{array}{l}\text { This } \\
\text { study }\end{array}$ \\
\hline Red teff & $664-1110$ & $233-297$ & $13-14$ & 77-102 & $\begin{array}{l}\text { MP- } \\
\text { AES }\end{array}$ & $\begin{array}{l}\text { This } \\
\text { study }\end{array}$ \\
\hline $\begin{array}{l}\text { Mixed } \\
\text { teff }\end{array}$ & $252-694$ & $253-286$ & $12.8-13$ & $69-87$ & $\begin{array}{l}\text { MP- } \\
\text { AES }\end{array}$ & $\begin{array}{l}\text { This } \\
\text { study }\end{array}$ \\
\hline
\end{tabular}

Daily recommended intake values

Injera made from teff floor is a staple food for Ethiopian people. It is consumed daily by almost every Ethiopian. Assuming that an average adult person consumes two injera (which are made from about $180 \mathrm{~g}$ teff floor) per day on average the amount of mineral intake by the person is shown in Table 8 . The amount of $\mathrm{Ca}$ that a person can get is lower than the daily recommended value. This indicates that teff alone cannot be a good source of the Ca needed for the daily requirement. Therefore the person must get supplementary Ca from other sources. The amount of $\mathrm{Fe}$ in an average size meal is sufficient for what is recommended for the daily need of an adult person. The amount of $\mathrm{Zn}$ that humans get from teff is in the range of the daily recommended intake [27]. The values for $\mathrm{Al}, \mathrm{Cu}, \mathrm{Mn}, \mathrm{Cd}$ and $\mathrm{Pb}$ are all above the allowable limits [27]. Teff in these areas has too many sources of these metals. Therefore a person should not consume foods from teff daily and should consume food from other cereals such as wheat, maize or rice at regular intervals. Since the level of the heavy metals $\mathrm{Cd}$ and $\mathrm{Pb}$ in the samples are above the allowable limit, it is possible to conclude that, the person is not free from the risks of $\mathrm{Cd}$ and $\mathrm{Pb}$ as a result of consuming teff food. Different agricultural practices like usage of fertilizers, pesticides, and other industrial products may be the sources of the contamination. Therefore, further studies must be done on large number of the samples from different regions of the country by using different analytical methods to assure the extent of $\mathrm{Cd}$ and $\mathrm{Pb}$ contamination in the teff. 
Table 8. Metal concentrations in teff (this study), the amount that an average adult human can get from 180 $\mathrm{g}$ teff per day, RDI and upper limit values of metals recommended by experts and agencies for a normal adult man [27].

\begin{tabular}{|l|l|l|l|l|}
\hline Metal & $\begin{array}{l}\text { Concentration } \\
\text { in teff }(\mathrm{mg} / \mathrm{kg})\end{array}$ & $\begin{array}{l}\text { Amount of metal human can } \\
\text { get from 180 g teff }(\mathrm{mg})\end{array}$ & $\begin{array}{l}\text { Recommended daily } \\
\text { intake }(\mathrm{RDI}) \text { [27] }\end{array}$ & $\begin{array}{l}\text { Tolerable upper } \\
\text { limit [27] }\end{array}$ \\
\hline $\mathrm{Fe}$ & $252-1195$ & $45-215$ & $9-17 \mathrm{mg}$ & $45 \mathrm{mg} / \mathrm{day}$ \\
$\mathrm{Ca}$ & $233-348$ & $42-63$ & $1000-1200 \mathrm{mg}$ & $2500 \mathrm{mg} /$ day \\
$\mathrm{Cu}$ & $13-15$ & $2.3-2.7$ & $0.9-2.3 \mathrm{mg}$ & $5 \mathrm{mg} / \mathrm{day}$ \\
$\mathrm{Zn}$ & $69-102$ & $12-18$ & $10-20 \mathrm{mg}$ & $40 \mathrm{mg} / \mathrm{day}$ \\
$\mathrm{Mn}$ & $20-45$ & $3.6-8$ & $1.8-2.3 \mathrm{mg}$ & $11 \mathrm{mg} / \mathrm{day}$ \\
$\mathrm{Al}$ & $713-1513$ & $128-272$ & $0.18-1.15 \mathrm{mg} / \mathrm{kg} \mathrm{bw} / \mathrm{week}$ & $1 \mathrm{mg} / \mathrm{kg} \mathrm{bw} / \mathrm{week}$ \\
$\mathrm{Cd}$ & $0.8-1.8$ & $0.14-0.32$ & $0.8 \mu \mathrm{g} / \mathrm{kg} \mathrm{bw} / \mathrm{day}$ & $7 \mu \mathrm{g} / \mathrm{kg} \mathrm{bw} / \mathrm{week}$ \\
$\mathrm{Pb}$ & $1.8-2.8$ & $0.32-0.50$ & $0.02-3 \mu \mathrm{g} / \mathrm{kg} \mathrm{bw} / \mathrm{day}$ & $25 \mu \mathrm{g} / \mathrm{kg} \mathrm{bw} /$ day \\
\hline
\end{tabular}

\section{Analysis of variance (ANOVA)}

One-way ANOVA was used to compare the mean values of the metals between different sampling sites at a 95\% confidence level [28]. There were a significant difference among the mean concentrations of $\mathrm{Al}, \mathrm{Ca}, \mathrm{Cd}, \mathrm{Fe}, \mathrm{Pb}$ and $\mathrm{Zn}$ found in the white teff samples collected from the three sampling areas, but no significant difference in the mean concentrations of $\mathrm{Cu}$ and $\mathrm{Mn}$ among the white teff samples. Similarly, there was a significant difference among the mean concentrations of $\mathrm{Al}, \mathrm{Ca}, \mathrm{Cd}, \mathrm{Fe}, \mathrm{Pb}, \mathrm{Cu}$ and $\mathrm{Zn}$ found in the red teff samples collected from the three sampling areas, but no significant difference in the mean concentrations of Mn among the red teff samples. Finally, there was a significant difference among the mean concentrations of $\mathrm{Al}, \mathrm{Ca}, \mathrm{Cu}, \mathrm{Fe}, \mathrm{Mn}$ and $\mathrm{Zn}$ found in the mixed teff samples collected from the three sampling areas, but no significant difference in the mean concentrations of $\mathrm{Cd}$ and $\mathrm{Pb}$ among the mixed teff samples. The presence of significant difference may be due to the presence of different geographical distribution, rainfall, soil composition, harvesting and storing methods.

\section{Pearson correlation of metals}

The Pearson product-moment correlation coefficient is the measure of the strength of a linear association between two variables [28]. A correlation coefficient of +1.0 indicates a perfect positive correlation while a correlation coefficient of -1.0 indicates a perfect negative correlation. Linear regression correlations tests were performed to investigate the correlations among the overall mean metal concentrations in the three varieties of tell samples collected from the three sampling areas. The results are summarized in Table 9. According to this study the highest correlation was seen between $\mathrm{Cu}-\mathrm{Ca}$ among the three types of teff. A higher correlation was also observed between $\mathrm{Fe}-\mathrm{Al}, \mathrm{Mn}-\mathrm{Cd}$ and low correlations for the others metals among the three types of teff.

Table 9. Pearson correlation coefficients of the metals.

\begin{tabular}{|l|l|l|l|l|l|l|l|l|}
\hline Metal & $\mathrm{Fe}$ & $\mathrm{Ca}$ & $\mathrm{Cu}$ & $\mathrm{Zn}$ & $\mathrm{Mn}$ & $\mathrm{Al}$ & $\mathrm{Cd}$ & $\mathrm{Pb}$ \\
\hline $\mathrm{Fe}$ & 1.0000 & & & & & & & \\
$\mathrm{Ca}$ & 0.3100 & 1.0000 & & & & & & \\
$\mathrm{Cu}$ & 0.4130 & $0.9510^{* *}$ & 1.0000 & & & & & \\
$\mathrm{Zn}$ & 0.2470 & -0.1890 & -0.2410 & 1.0000 & & & & \\
$\mathrm{Mn}$ & -0.0420 & -0.3300 & -0.2450 & 0.3580 & 1.0000 & & & \\
$\mathrm{Al}$ & 0.6380 & 0.4610 & 0.5500 & 0.2600 & 0.3640 & 1.0000 & & \\
$\mathrm{Cd}$ & 0.0320 & -0.1810 & -0.1310 & -0.5680 & -0.5950 & -0.3750 & 1.0000 & \\
$\mathrm{~Pb}$ & -0.3360 & 0.2190 & 0.1390 & -0.4650 & -0.0370 & -0.0180 & 0.1760 & 1.0000 \\
\hline
\end{tabular}

**Correlation is significant at the 0.01 level. 


\section{CONCLUSION}

An efficient digestion procedure for the determination of metals in the teff grain samples was optimized and validated through spiking method and a good percentage recovery was obtained for the metals of interest. The mean concentration levels of the metals in the three varieties of teff samples collected from the three sampling areas indicated that higher concentrations of Al and $\mathrm{Fe}$ were found in the white teff samples collected from Bure sampling area. Likewise, higher concentrations of $\mathrm{Al}$ and $\mathrm{Fe}$ were found in the red and mixed teff samples collected from Debre Markos and Bahir Dar areas.

The overall mean concentrations determined $(\mathrm{mg} / \mathrm{kg}$, dry weight) was in the ranges of $\mathrm{Al}$ $(713-1513)>\mathrm{Fe}(252-1195)>\mathrm{Ca}(233-348)>\mathrm{Zn}(69-102)>\mathrm{Mn}(20-45)>\mathrm{Cu}(13-15)>\mathrm{Pb}$ $(1.8-2.8)>\mathrm{Cd}(0.8-1.8)$. The results indicate that teff grain is a good source of essential metals but not free from the toxic metals $\mathrm{Cd}$ and $\mathrm{Pb}$. The accuracy of the optimized procedure was evaluated by analyzing the digest of the spiked samples with standard solution and the percentage recoveries varied from $92 \%$ to $104 \%$ which is good and is in the allowed range of $90 \% \pm 10[28]$.

The ANOVA results at $95 \%$ confidence level suggest that there were no significant difference between the mean concentrations of $\mathrm{Cu}$ and $\mathrm{Mn}$ among the white teff samples, $\mathrm{Mn}$ among the red teff samples and $\mathrm{Cd}$ and $\mathrm{Pb}$ among the mixed teff samples, but there were a significant difference for the other studied metals among the corresponding teff samples. Since the levels of the toxic elements $\mathrm{Cd}$ and $\mathrm{Pb}$ in the teff samples are above the allowable limit, it is possible to conclude that a person who consumes teff produced from this sampling areas is not free from the risks of $\mathrm{Cd}$ and $\mathrm{Pb}$, this may be caused due to the contamination of the samples. Different agricultural practices like usage of fertilizers, pesticides, and other industrial products may be the sources of the contamination. Therefore, further studies must be done on large number of the samples from different regions of the country by using different analytical methods to assure the extent of $\mathrm{Cd}$ and $\mathrm{Pb}$ contamination in the teff.

\section{ACKNOWLEDGEMENTS}

The authors express their gratitude to the Department of Chemistry, Addis Ababa University, Ethiopia, for providing the laboratory facilities. Abraha Gebregewergis is also thankful to the Ethiopian Institute of Agricultural Research, Addis Ababa, Ethiopia, for sponsoring his study.

\section{REFERENCES}

1. Vinning, G.; McMahon, G. A demand and supply analysis of prospects for the Australian health grains industry, A report for the rural industries research and development corporation, 2006. Available at: https://www.agrifutures.com.au/wpcontent/uploads/publications/05-011.pdf.

2. Kibatu, G.; Chacha, R.; Kiende, R. Determination of major, minor and trace elements in teff using portable total X-ray fluorescence (TXRF) spectrometer. EC Nutrition 2017, 9, 51-59.

3. Merga, M. Progress, achievements and challenges of tef breeding in Ethiopia. J. Agric. Sci. Food Res. 2018, 9, 1-8.

4. Coleman, J.M. Assessing the potential use of teff as an alternative grain crop in Virginia. Master Thesis, Verginia Technology, 2012. Available at: http://hdl.handle.net/10919/77012.

5. Boka, B.; Woldegiorgis, A.Z.; Haki, G.D. Antioxidant properties of Ethiopian traditional bread (injera) as affected by processing techniques and tef grain (Eragrostistef (Zucc.)) varieties. Canadian Chem. Trans. 2013, 1, 7-24. 
6. Baye, K.; Mouquet-Rivier, C.; Icard-Vernière, C.; Rochette, I.; Guyot, J.-P. Influence of flour blend composition on fermentation kinetics and phytate hydrolysis of sourdough used to make injera. Food Chem. 2013, 138, 430-436.

7. Adebowale, A.A.; Naushad Emmambux, M.; Beukes, M.; Taylor, J. Fractionation and characterization of teff proteins. J. Cereal Sci. 2011, 54, 380-386.

8. do Nascimento, K.d.O.; Paes, S.d.N.D.; de Oliveira, I.R.; Reis, I.P.; Augusta, I. M. Teff suitability for different food applications and as a raw material of gluten-free, a literature review. J. Food Nutr. Res. 2018, 6, 74-81.

9. Miller, E. Physico-chemical properties of teff. Minerals in Food Chemistry, 1996. Available at: https://www.scribd.com/document/328314097/Food-Chemistry-O-R Fennema.

10. Mason, R. The Minerals You Need, USA: Safe Goods Publishing; 2011, 2, 45-78.

11. Gueguen, L.; Pointillart, A. The bioavailability of dietary calcium. J. Am. Coll. Nutr. 2000, 19, 119S-136S

12. Al-Fartusie, F.S.; Mohssan, S.N. Essential trace elements and their vital roles in human body. Indian J. Adv. Chem. Sci. 2017, 5, 127-136.

13. Baye, K.; Mouquet-Rivier, C.; Icard-Vernière, C.; Picq, C.; Guyot, J.-P. Changes in mineral absorption inhibitors consequent to fermentation of Ethiopian injera: Implications for predicted iron bioavailability and bio-accessibility. Int. J. Food Sci. Technol. 2014, 49, 174180.

14. Dame, Z.T. Analysis of major and trace elements in teff (Eragrostistef). J. King Saud Univ. - Sci. 2020, 32, 145-148.

15. Saturni, L.; Ferretti, G.; Bacchetti, T. The gluten-free diet: safety and nutritional quality. Nutrients 2010, 2, 16-34.

16. Bokhari, F.; Derbyshire, E.; Li, W.; Brennan, C.S.; Stojceska, V. A study to establish whether food-based approaches can improve serum iron levels in child-bearing aged women. J. Human Nutr. Dietetics 2012, 25, 95-100.

17. Berhane, G.; Paulos, Z.; Tafere, K.; Tamiru, S. Food grain consumption and calorie intake patterns in Ethiopia. Development Strategy and Governance Division, International Food Policy Research Institute, Ethiopia Strategy Support Program II (ESSP II), ESSP II Working Paper No. 23, 2011.

18. Takáč, P.; Szabová, T.; Kozáková, L.; Benková, M. Heavy metals and their bioavailability from soils in the long-term polluted Central Spiš Region of SR. Plant Soil Environ. 2009, $55,167-172$.

19. Boke, A.; Megersa, N.; Teju, E. Quantitative determination of the heavy metal levels in the wild edible plant parts and their corresponding soils of the central and western regions of the Oromia state, Ethiopia. J. Environ. Anal. Toxicol. 2015, 5, Article 299.

20. Zeleke, K. Levels of essential elements in three teff [Eragrostistef (Zucc.) Trotter] varieties. Master Thesis, Addis Ababa University, 2009. Available at https://books.google.com.et/books?id=HYoZBQAAQBAJ.

21. Ayana, G.; Amare, M. Determination of the iron content of soil and cultivated white teff from Parzete and Zeghi Kebele, Debatie Wereda Metekel Zone, Benshangul Gumuz, Ethiopia. Int. J. Innov. Pharm. Sci. Res. 2017, 5, 11-32.

22. Yilmaz, H.O.; Arslan, M. Teff nutritional compounds and effects on human health. Acta Sci. Med. Sci. 2018, 2, 15-18.

23. Abebe, Y.; Bogale, A.; Hambidge, K.M.; Stoecker, B.J.; Bailey, K.; Gibson, R.S. Phytate, zinc, iron and calcium content of selected raw and prepared foods consumed in rural Sidama, Southern Ethiopia and implications for bioavailability. J. Food Compos. Anal. 2007, 20, 161-168. 
24. Gebremariam, M.M.; Zarnkow, M.; Becker, T. Teff (Eragrostistef) as a raw material for malting, brewing and manufacturing of gluten-free foods and beverages: A review. J. Food Sci. Technol. 2014, 51, 2881-2895.

25. Abebe, A.; Chandravanshi, B.S. Levels of essential and non-essential metals in the raw seeds and processed food (roasted seeds and bread) of maize/corn (Zea mays L.) cultivated in selected areas of Ethiopia. Bull. Chem. Soc. Ethiop. 2017, 31, 185-199.

26. Tegegne, B.; Chandravanshi, B.S.; Zewge, F. Levels of selected metals in commercially available rice in Ethiopia. Int. Food Res. J. 2017, 24, 711-719.

27. Food and Agriculture Organization of the United Nations and World Health Organization. $\mathrm{FAO} / \mathrm{WHO}$ guide for application of risk analysis principles and procedures during food $\begin{array}{lll}\text { safety emergencies. FAO/WHO: Rome; } & \\ \text { http://www.fao.org/docrep/014/ba0092e/ba0092e00.pdf. }\end{array}$

28. Miller, J.N.; Miller, J.C. Statistics and Chemometrics for Analytical Chemistry, 5th ed., Pearson Practice Hall: England; 2005; pp 55-72. 